\title{
A EMERGÊNCIA DE NAÇÕES NO MUNDO MUÇULMANO DO MÉDIO-ORIENTE E DA ÁFRICA DO NORTE
}

SUZANNE DAVEAU

O espesso manual de Geografia política, publicado em 1993 por Xavier de Planhol(1), é consagrado ao coração histórico do Mundo islâmico, que se estende do litoral atlântico marroquino até ao Afeganistão (fig. 1). Este vasto espaço enquadra directamente, ao Sul e a Leste, a Europa de civilização cristã e constitui para ela um vizinho perturbante, pela sua grande complexidade e pela repetida agitação que numerosos conflitos lhe conferem. Esses conflitos parecem tanto mais inquietantes aos Europeus quanto mais difíceis de entender são as suas causas.

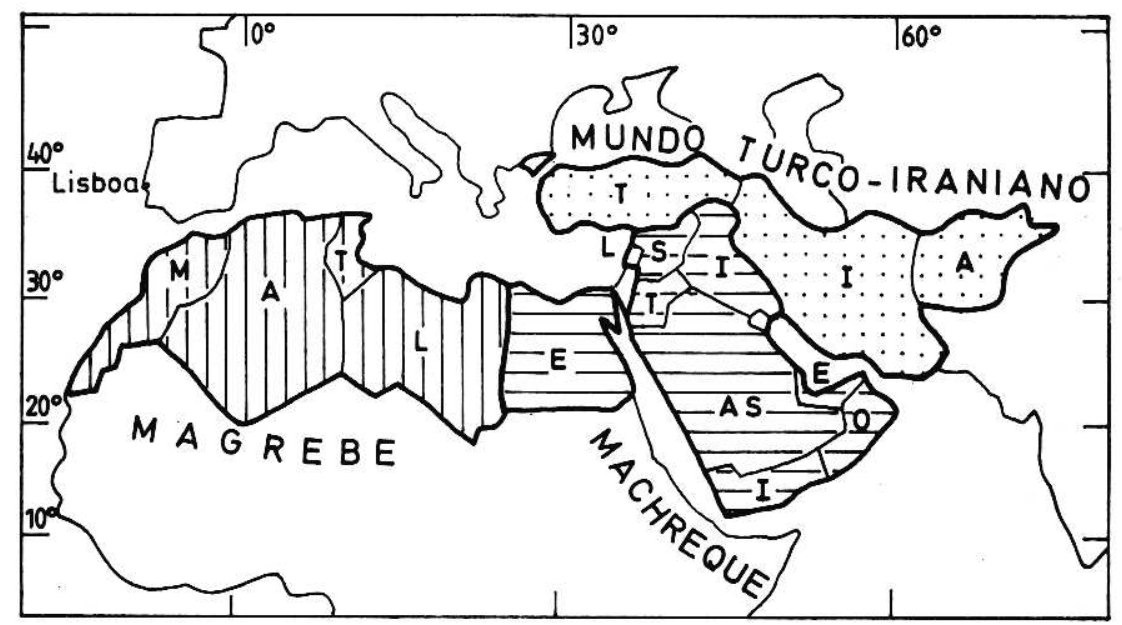

Figura 1 - As nações estudadas

(1) Xavier de Planhol, Les Nations du Prophète. Manuel géographique de politique musulmane, Paris, Fayard, 1993, 894 p. 
Surge assim, com uma importância muito grande, a rica e erudita contribuição de um geógrafo que consagrou a maior parte da sua vida de investigador à compreensão do Mundo mediterrâneo, encarado principalmente nas suas componentes islâmica e turca. Sempre atraído pelos problemas de Geografia histórica e cultural ${ }^{(2)}$, Xavier de Planhol pertence ainda à geração dos geógrafos que receberam uma formação ampla e equilibrada, e que nunca a renegaram, mesmo quando o seu percurso pesșoal os levou às mais variadas especializações. Não hesita, por isso, sempre que necessário, a tomar em conta o peso, às vezes grande, que os aspectos naturais têm nos intricados problemas de Geografia política que estuda. Outra qualidade fundamental deste estudo é a perspectiva histórica que ilumina constantemente as suas análises. As construções de nações, em muitos casos ainda imperfeitas, que se observam na actualidade, têm, não raro, raízes profundas e levam a marca de civilizações sucessivas.

O fio condutor do livro, que se quer um "manual geográfico de política muçulmana", é a tentativa para compreender a emergência, mais ou menos recente e conseguida, de "nações", no sentido europeu da palavra, no vasto domínio nuclear da civilização islâmica. A implantação "da alma e do corpo" de um povo num espaço terrestre bem delimitado, caso tão evidente hoje para muitos Europeus e, em especial, para a maior parte dos Portugueses, encontra-se em profunda contradição com o ideal muçulmano da aspiração à unidade de todos os homens crentes na submissão à lei de um Deus único. E é também contrária à outra tendência ideológica muito viva nesta parte do Mundo: o arabismo. A análise destas contradições e das soluções variadas que foram encontradas é o ponto de vista que dá coerência ao estudo dos numerosos e tão diversos países, sucessivamente apresentados no liviro.

Não se resume um denso manual de mais de 700 páginas de texto, com 61 figuras de grande densidade informativa, 50 páginas de referências bịliográficas e um índice geral de 36 páginas em dupla coluna e corpo pequeno. Quando muito, pode dar-se uma ideia muito esquemática da sua estrutura e conteúdo, afirmando-se, desde já, que este livro, que condensa vastos conhecimentos sobre os países de que trata, é, no entanto, de leitura sempre fácil. Esta torna-se, até, muitas vezes entusiasmante, por fornecer a chave de nume-

(2) Assinalam-se, entre as obras recentes de Xavier de Planhol, a Géographie Historique de la France, Fayard, Paris, 1988, 635 p. e L'Eau de Neige. Le Tiède et le Frais. Histoire et Géographie des boissons fraîches, Fayard, Paris, 1995, 474 p. Acaba também de se publicar um Livro de Homenagem, dedicado ao Prof. Xavier de Planhol: Géographie Historique et Culturelle de l'Europe, Presses de l'Université de Paris-Sorbonne, Paris, 1995, 423 p., que contém a lista das obras do homenageado. A contribuição portuguesa, de Orlando Ribeiro e colaboradores, apresenta um balanço sobre "Les recherches de Géographie historique au Portugal". 
rosos problemas geográficos e políticos, iluminando temas intrincados que o leitor nunca tinha conseguido perceber.

A presente obra de $\mathrm{X}$. de Planhol constitui uma renovada demonstração do profundo poder explicativo do método geográfico, quando bem praticado, segundo a linha constantemente enriquecida e renovada da Geografia regional tradicional, entendida como o estudo conjunto e evolutivo da Terra e do Homem.

Uma sinopse do índice do livro afigura-se a melhor maneira de dar sucintamente conta do seu conteúdo e estrutura. Uma introdução metodológica (p. 15-59) realça o papel dos dois grandes motores da organização do espaço no Mundo muçulmano (as cidades e os grupos nómadas), com uma grande diversidade regional dos seus modos de acção. A seguir são apresentados os actuais Estados, agrupados em três grandes conjuntos: o Machreque (Oriente) (p. 61-296), o Magrebe (Ocidente) (p. 297-476) e o Mundo turco-iraniano (p. 477-739).

O estudo do Machreque começa pela apresentação da Península Arábica: o Deserto e as suas Margens, com oposição entre o coração, a enorme Arábia Saudita, e os pequenos Estados circundantes, Transjordânia, Iémen, Oman e Emiratos. Segue-se o estudo comparativo do papel das Cidades e das Serras na Síria e no Líbano, e, outra vez comparativamente, a do domínio desigual que duas velhas civilizações agrárias baseadas no regadio conseguiram sobre a Terra e as Águas, com consequências bem diferentes para a solidez das actuais entidades nacionais do Egipto e do Iraque.

A análise do Magrebe começa pela apresentação das principais Componentes que lhe dão originalidade: o papel das populações berberes, em geral sedentárias, frente aos potentes grupos nómadas, e a acção dos dois elementos organizadores, as cidades e as sucessivas colonizações. As quatro Entidades nacionais resultantes apresentam-se a seguir, sendo cada uma provida de forte personalidade e de problemas bem diferentes: a Tunísia, Marrocos, a Argélia e a Líbia.

A especificidade e diversidade interna do Mundo Turco-Iraniano resulta, em grande parte, segundo X. de Planhol, do impacto que a Dominação turca teve sobre a brilhante e sólida civilização iraniana e sobre a mais frágil impregnação helenística da Ásia Menor. Estudam-se sucessivamente o peso da tradição e da organização imperial frente às diversas nacionalidades periféricas na elaboração em curso de uma nação no Irão, o Afeganistão como persistente anti-nação e, finalmente, a Turquia, onde se constituiu uma nação indiscutível, a despeito das forças centrífugas dos Chiitas e dos Curdos. 